ISSN: 2162-3104 Print/ ISSN: 2166-3750 Online

Volume 8, Issue 3 (2018), pp. 1293-1315

(C) Journal of International Students

http://jistudents.org/ doi: 10.5281/zenodo.1254584

\title{
Communications Preferences Among International Students: Strategies for Creating Optimal Engagement in Programs and Services
}

\author{
Ravichandran Ammigan \\ University of Delaware, USA \\ Kaitlyn N. Laws \\ University of Delaware, USA
}

\begin{abstract}
As U.S. institutions continue to welcome larger and more diverse populations of international students, campus support offices are also expected to adjust their programming and outreach strategies to engage a wider student audience and provide them with key information and services. This quantitative study examines the communications preferences of degreeseeking international students enrolled in a mid-size U.S. university. It specifically investigates students' preferred methods of communication, patterns and frequency in sending and receiving messages, and the types of information they prefer to be informed of. The survey also looks across a number of communication media including email, social media, print communications, and face-to-face interactions to better understand how resources may be directed to individual channels. The authors argue that the most impactful engagement model requires an accompanying, analyticsdriven communications strategy to support international students during their stay on campus.
\end{abstract}

Keywords: communications preferences, international students, student engagement, support services

International student enrollment at U.S. institutions of higher education has soared by over $85 \%$ in the last decade, reaching a record high of over a million in 2017 (Institute of International Education, 2017). As a larger, 
more diverse population of students seek opportunities for higher education, an ever-expanding and innovative programming and support model is needed. These programs and services are generally offered by the International Student Services (ISS) office to assist international students with visa and immigration issues, support their academic, social, and cultural success, and engage them with domestic students, faculty, and staff (Choudaha \& Schulmann, 2014).

While a number of universities have successfully built these comprehensive and collaborative models for programming, we contend that optimal impact is achieved through the addition of a strong communications strategy for matriculated international students. Analyzing data from a 2017 quantitative study, this article explores the communications preferences of degree-seeking international students at a mid-size U.S. university and proposes a holistic strategy for driving key audiences to engage more effectively. Specifically, the digitally-deployed survey looks across a number of communication media including email, social media, print communications, and face-to-face interactions.

We define communications strategy, based on a definition from Steyn (2002), as a thinking document that guides communications goals, values, actions, and metrics to inform further improvement. Operating in a day and age where technology and information systems are readily available, it is easy to assume that ISS offices have already developed datadriven communications strategies to serve their audiences. However, this might not necessarily be the case in practice. To get a sense of how ISS offices were equipped to support the communication needs of their international student community, we ran a preliminary survey among 42 of the university site's comparator and partner institutions in the U.S. Of those institutions, 36 responded, representing 22 states and international student enrollments ranging from 15 to 17,326. Among those who responded, eight suggested that their office maintained a communications plan and only two reported regular collaboration with their university's central department of communications and marketing. Further, just one institution indicated having a dedicated, full-time communications staff person. Among the respondents' comments, many confirmed that they were sending messages out to students but were not guided by a dedicated communications strategy or had the necessary support and expertise to develop one. Others indicated the need to revise or rework what currently exists so they could be more effective in reaching out to their international student community. One participating institution enrolling over 10,000 international students defined communications strategy as an intentional effort that is "streamlined, 
coordinated, and transparent" and highlighted the importance of establishing a communication plan as part of their ISS office priorities.

This article aims to contribute to the literature on the responsibility of specialized support from ISS offices, whose role it is to collaborate with partner offices as well as understand, reach, and serve international students. In addition, this study serves as an example of one institution's efforts to align communications strategy with international students' needs and preferences.

\section{LITERATURE REVIEW}

As the number of international students studying in the United States continues to grow, many have posited whether the international and domestic student experience differ from each other. While some have argued that segmenting the international student audience can be problematic and result in over-generalization (e.g., Jones, 2017), several studies have pointed to their unique experience on university and college campuses (Smith \& Khawaja, 2011; Sherry \& Chui, 2010; Lee \& Rice, 2007; Hayes \& Lin, 1994). International students face a number of distinct challenges as they transition to the U.S. and throughout their studies ranging from the administrative burden of visa compliance, language barriers, and work constraints to a reduced sense of belonging and inclusiveness (Choudaha \& Schulmann, 2014; Smith \& Demjanenko, 2011). While all students must adjust to a new life in college, international students tend to have greater difficulty in doing so (Kaczmarek, Matlock, Merta, Ames, \& Ross, 1994).

In order to address these challenges and to leverage the international community as a key component in campus internationalization, International Student Services (ISS) offices have developed intentional programming. Collaborative in nature, these programs promote academic success, understanding of government regulations, intercultural understanding, and connect students, scholars, and their family members to the local community. As these strategies continue to develop, an accompanying communications plan must follow (Briggs \& Ammigan, 2017). Even the most effective programming and outreach strategy may not be successful without its communications counterpart.

\section{International Student Engagement}

The recruitment and enrollment of international students to campus is one of the many aspects of campus internationalization at institutions of higher education (Vincent-Lancrin, 2007). Internationalization, defined by Knight (2015, p. 2) as "the process of integrating an international, 
intercultural, or global dimension into the purpose, functions or delivery of postsecondary education," translates into how universities prepare their students to acquire global perspectives and navigate the social and cultural contexts throughout their program of study (Burdett \& Crossman, 2012). While student engagement has been studied extensively for American students, this has not been the case for international students, who choose to study in the U.S. for a variety of reasons including academic and research excellence, campus life, support services, and career prospects (Korobova, 2012).

About $80 \%$ of traditional-aged undergraduate students engage in one or more extra-curricular activities (Knapp, 1979). Research shows that meaningful interactions between international and domestic students can assist international students' academic performance and sociocultural adjustment (Dunne, 2009). For instance, certain student organizations and extra-curricular activities not only promote student achievement but also increase general satisfaction with the academic experience (Astin, 1993). The more involved that college students are in the academic and social aspects of campus life, the more they may benefit in terms of learning and personal development. Campus involvement and engagement during their college years can impact students' social, communication, and interpersonal skills in the workplace, and increase their chance of graduate program acceptance (Dunkel, Bray, \& Wofford, 1989).

Understanding what international students need to be successful in their academic, social, and community settings has been a significant foundation for achieving student success at many institutions (Abe, Talbot, \& Geelhoed, 1998). Additionally, the increased complexity in immigration regulations, international travel, and risk management has stressed the importance for ISS offices to provide key information to their international student community about visa compliance standards in the U.S. (Rosser, Hermsen, Mamiseishvili, \& Wood, 2007).

While further research is needed for university administrators and support service offices to better understand the experience of international students and identify factors contributing to their involvement on campus, more programs and services that stimulate their engagement in purposeful and educational activities are crucial. Meeting the needs of all students in increasingly diverse university communities can be challenging and requires a well-articulated and collaborative programming and outreach plan.

Table 1 lists examples of programs that ISS offices generally host in collaboration with their campus stakeholders to engage and involve international students. It is adapted from Briggs and Ammigan's (2017) collaborative model for international student programming and was 
developed to address the needs of students and support the overall global engagement and campus internationalization efforts of the institution.

Table 1. Examples of ISS programs.

\begin{tabular}{|c|c|c|}
\hline & Programs & Stakeholders \\
\hline $\begin{array}{l}\text { To support } \\
\text { academic } \\
\text { success }\end{array}$ & $\begin{array}{l}\text { U.S. culture series; Tutoring } \\
\text { services; Time management and } \\
\text { study skills; Academic honesty } \\
\text { and plagiarism; Working with } \\
\text { your TA; Language support } \\
\text { programs; Resume building; } \\
\text { Navigating the library; Coping } \\
\text { with culture shock; Managing } \\
\text { stress; Dealing with expectations }\end{array}$ & $\begin{array}{l}\text { Office of Academic } \\
\text { Enrichment; TA Office; } \\
\text { Writing Center; Tutoring } \\
\text { Services; University } \\
\text { Library; Office of the } \\
\text { Ombudsman; Career } \\
\text { Services; Counseling } \\
\text { Center; Student Wellness; } \\
\text { Graduate Office }\end{array}$ \\
\hline $\begin{array}{l}\text { To understand } \\
\text { government } \\
\text { regulations }\end{array}$ & $\begin{array}{l}\text { Maintaining your legal status; } \\
\text { Employment options; Finding an } \\
\text { internship; Travel advisories; Tax } \\
\text { compliance issues; Healthcare and } \\
\text { insurance; Personal safety; Title } \\
\text { IX workshops; Social Security } \\
\text { number and driver's license }\end{array}$ & $\begin{array}{l}\text { Office of General Counsel; } \\
\text { Research Office; Student } \\
\text { Health Services; Law and } \\
\text { Tax Clinics Campus Police } \\
\text { and Safety; Human } \\
\text { Resources; Office of Equity } \\
\text { and Inclusion }\end{array}$ \\
\hline $\begin{array}{l}\text { To promote } \\
\text { international } \\
\text { understanding }\end{array}$ & $\begin{array}{l}\text { Weekly coffee hour; Ice cream } \\
\text { socials; Essay contest; Welcome } \\
\text { reception; Making friends across } \\
\text { cultures; Residence Life } \\
\text { programs; Intercultural } \\
\text { communication workshops; Film } \\
\text { series; Bowling nights; Global } \\
\text { festivals; Karaoke night }\end{array}$ & $\begin{array}{l}\text { Student Affairs, Residence } \\
\text { Life and Housing; } \\
\text { Multicultural Center; } \\
\text { Recreational Services; } \\
\text { Student Center; Student } \\
\text { Organizations; Athletics; } \\
\text { Various campus and } \\
\text { community partner offices }\end{array}$ \\
\hline $\begin{array}{l}\text { To connect } \\
\text { with the local } \\
\text { community }\end{array}$ & $\begin{array}{l}\text { Cultural excursions and field trips; } \\
\text { Networking with community } \\
\text { leaders; Holiday events and } \\
\text { receptions; Tailgating party; Host } \\
\text { family program; Speaker series }\end{array}$ & $\begin{array}{l}\text { City Manager's Office; } \\
\text { Host families; Office of } \\
\text { Community Engagement } \\
\text { and Service Learning; } \\
\text { Rotary Club; Kiwanis Club }\end{array}$ \\
\hline
\end{tabular}

\section{International Student Communications}

Outside of the sphere of ISS and across the field of higher education as a whole, institutions have been tasked with creating targeted and compelling communications strategies. Gikas and Grant (2013) found that $67 \%$ of surveyed students identified that mobile devices contributed to their academic success. Later, in 2016, the Education Advisory Board (EAB) conducted a study that found just over half of their respondents, $54 \%$, say 
that they choose to filter their emails from their academic department selectively (Education Advisory Board, 2016). In an environment where all students are required to complete a myriad of tasks and meet many deadlines, university units must reach students where they are with relevant, timely, and engaging messages. As such, EAB and others have called for universities to integrate digital channels into their communications plans and to deploy clear, optimized messages.

Others within the field have also suggested a more measured approach to international student recruitment. The Hobsons Insight Series proposed that universities in the UK should adopt a "student-centered" approach to their recruitment efforts, using insights from accessible and affordable data to build a target market, to understand their mindset and deliver a personalized product (Hobsons Solutions, 2016). The i-graduate report, "A UK Guide to Enhancing the International Student Experience" (Archer, Jones, \& Davison, 2010), also reiterates this need for a metricsdriven approach, recommending that universities develop a strategy for assessment of performance amongst both international and domestic audiences. In addition, the report points directly to a gap between expectations and delivery when it comes to pre-arrival communications.

Over the last decade, several studies have aimed to dig deeper into international student communications preferences and user behavior, particularly when it comes to the role of social media. In an Australian study, Khawaja and Stallman (2011) identify several coping techniques which international students employed as they transitioned to life as an international student. Technology emerged as a well-established medium and students reported the utility of email and social media to both maintain contact with friends and family at home, establish new networks in the U.S., and explore useful information during the transition. Saha and Karpinski (2016) reaffirm this finding in a U.S. survey, which found that the use of social media, specifically Skype, is positively related to international students' satisfaction with life at their university. Lin et al. (2012), too, found that Facebook usage was positively related to international students' online bridging capital.

In a recent study, Saw, Abbott, and Donaghey (2013) demonstrate that the social media preferences of international and domestic students "differ only marginally" and that while Facebook may be the most popular social networking sites for international students they surveyed, it did not have exclusive access to the market. YouTube, Twitter, and LinkedIn followed behind and some variation based on country of origin was evident. The study also indicates some disparity between personal and institutional 
interests on social media, with about a third of students specifying that they would like to keep their social and academic lives separate.

In the United States, China remains the top sender of international students, consisting of $31.5 \%$ of all international students enrolled at institutions in 2016. At the university site in this study, Chinese students made up $62 \%$ of the international student population in that same year. Saw, Abbott, and Donaghey's (2013) study showed that, while all Chinese respondents did report having a Facebook account, 62\% had created it within the previous two years and $12 \%$ did not use the social networking site at all.

It must be noted that very limited literature exists on communications preferences of international students in the U.S. outside the realm of social media. A report from the Office of Student Life at Ohio State University (2017) shows that, while statistically significant differences did exist between international and domestic students, email was the preferred method of communication across the board.

In Australia, several have mapped the information seeking of international students both before their arrival to Australian institutions and after matriculation (Alzougool et al., 2013; Chang and Gomez, 2016). These studies have found that while there are many available online and offline sources, in general, students look to a single source for their information. With no one source reigning supreme amongst the sample populations, the literature argues for a holistic communications approach. In addition, these studies suggest that students who are connected to local social networks tend to consume more diverse sources of information. Offline sources like word of mouth retain their importance, more so for less connected students. While these studies do focus exclusively on the Australian context and rely on small or undisclosed sample sizes, the authors pose relevant topics for future research. These include how ISS offices may tailor their communications efforts to a diverse audience and whether institutional efforts are appropriately aligned with their audiences' needs. This article demonstrates one U.S. institution's metrics-driven approach to optimize their communications strategy in this way.

\section{Strategic Communication}

Steyn (2002) defines strategy as the thinking behind the operations and the positioning of values for future use. Similarly, Hallahan et al. (2007) define strategy as the development, implementation, and assessment of communications. They continue by adding that strategic communication is intentional and should be driven by research and scholarship in the field. Argenti, Howell and Beck (2005) reiterate the need for intention, defining 
strategic communication as an integral communication approach that is aligned with the organization's overall strategy and one that enhances its positioning and supports its outreach function to key constituencies. Many organizations often use short-term, reactive approaches, which is not only nonstrategic in nature but may be inconsistent with or even impede its overall institutional communication strategy.

Communications plans are communication strategy in action. According to the Center for Community Health and Development at the University of Kansas (University of Kansas, n.d.), communications plans follow the following eight step process: 1) identify the purpose of the communication; 2) identify the audience; 3) plan and design the message; 4) consider available resources; 5) plan for obstacles and emergencies; 6) strategize how to connect with the media and others who can help spread your message; 7) create an action plan; and 8) decide how to evaluate and adjust the plan, based on feedback received.

\section{RESEARCH METHOD}

This quantitative study examines the communications preferences of degreeseeking international students in an effort to foster engagement and enhance their experience on campus and in the local community. In particular, it investigates students' preferred methods of communication, patterns, and frequency in sending and receiving messages, and the types of information of which they would like to be informed. The survey also looks across a number of communication media including email, social media, print communications, and face-to-face interactions.

\section{Participants}

The sample consisted of 113 international degree-seeking students, who were enrolled during the 2017 spring semester at a mid-size 4-year university in the Mid-Atlantic region, referred to as "the university site." Approximately $43 \%(n=48)$ of the respondents were master's students, $37 \%(n=42)$ were doctoral students, and $20 \%(n=23)$ were undergraduate students. These sample demographic characteristics align well with the total population of international students studying at the university site, which enrolled a total of 2,606 international students (1,309 graduate students, 798 undergraduate students). International students at the university site represent $13 \%$ of all enrolled undergraduate and graduate students. Of the 33 countries represented in the sample, $36 \%(n=41)$ were from China, $18 \%$ $(n=21)$ were from India, and 9\% $(n=10)$ were from Iran. Approximately $65 \%(n=73)$ of participants had been students at the university for 2 years 
or more. About $98 \%(n=111)$ reported that they were proficient in reading, listening, and speaking the English language. Of those who responded, 81\% $(n=92)$ felt that they were comfortable with and understood the language and jargon used on U.S.-run social media accounts. The demographic characteristics of respondents are represented in Table 2.

Table 2. Demographic characteristics of respondents $(N=113)$.

\begin{tabular}{lcc}
\hline Demographic Variables & $n$ & Proportion \\
\hline Level of study & & \\
Masters & 48 & $42.5 \%$ \\
Doctorate & 42 & $37.2 \%$ \\
$\quad$ Undergraduate & 23 & $20.4 \%$ \\
Top countries of origin & & \\
China & 41 & $36.3 \%$ \\
India & 21 & $18.6 \%$ \\
Iran & 10 & $8.8 \%$ \\
Average time at university & 113 & 7 months \\
Proficiency in English language & 111 & $98.2 \%$ \\
\hline
\end{tabular}

\section{Instrument}

We developed a four-component online instrument, which was initially established for internal office-related purposes. The survey consisted of 17 closed-ended questions, using the Qualtrics Survey Software for this study (see Appendix A). We then piloted the survey with a small, randomly-selected sample of the survey population and finalized before launching to a wider audience. The first section of the survey focused on the preferred methods of communication and their frequency of use by international students to send and receive information at the university site. The second section gathered data on the types of social media channels students used both in their home country and in the U.S. The third set of questions was focused on content that students prefer to receive from their support office and in turn share back with others in their community. The last part of the survey was designed to obtain demographic data on student respondents, such as country of origin, level of study, and length of time at the university at the time they took the survey. The instrument used a 6point Likert scale to measure the use of communications methods, ranging from Very Frequently to Never, and a 5-point scale to measure interest in messaging content, ranging from Very Interested to Very Uninterested. Cronbach's alpha was assessed for the communication preferences variables as .91, indicating internal consistency of the variables in the scale. 


\section{Procedure}

Before launching the survey, we obtained approval from the university site's Institutional Review Board for research on human subjects. The ISS office generated a query of all registered undergraduate and graduate international students, then used this to invite participants to take the online survey via email. International students completed the questionnaire anonymously and were assured of the confidentiality of their responses. The non-identifiable data were stored and still reside on a secure university server, only accessible by the researchers. For the purpose of this study, an international student was defined as a full-time enrolled, degreeseeking student holding non-immigrant visa status in the U.S. It did not include short-term English as a Second Language students, visiting scholars and researchers, international employees, legal permanent residents, and other immigrant visa holders.

\section{Data Analysis}

We imported the data into IBM's SPSS Statistics software (Version 24) for quantitative analysis and developed a codebook to serve as a guide for defining variables and coding responses. Both descriptive statistics (percentages, means, and standard deviations) and inferential statistics (paired sample t-tests) were used to analyze the data. Paired-sample t-tests were used to compare the means of two communication variables within the same group and determine whether the mean difference between the paired observations was statistically significant. A homogeneity test was also conducted to identify any outliers in the analysis of communication preferences. All assumptions regarding the use of paired samples t-test analyses were met with the exception of the following variables, which failed the Levene's test and homogeneity of variance assumption $(p<.05)$ : Social Media (Send), YouTube (Home), and QQ (Home). Paired-samples ttests that included these variables were not found to be significant.

\section{RESULTS}

\section{Methods of Communication}

International students selected from a list, the communication methods they use to regularly send important information as students at the university. Email $(M=5.51)$ was the most frequently-used method of communication, followed by Face-to-Face Interactions $(M=4.47)$, and Social Media $(M=3.94)$. Students used Paper Communications $(M=2.79)$, in the form of letters, memos, posters, etc., rarely to convey information to others. When asked which forms of communication they received and 
observed important information in, international students correspondingly selected Email as the most frequent $(M=5.66)$, followed by Face-to-Face Interactions $(M=4.22)$, Social Media $(M=4.03)$, and Paper Communications $(M=3.38)$.

We conducted paired-samples t-tests to compare the means of sending and receiving messages by the different methods of communication. There was a significant average difference in the scores for sending and receiving Paper Communications $[t(112)=-4.87, p<.001]$, as well as in Face-to-Face Interactions $[t(112)=2.92, p<.001]$. These results suggest that international students prefer to receive rather than send communications in paper format. They also prefer to use Face-to-Face Interactions when giving important information rather than when receiving information. Conversely, there was no significant average difference in how international students used Email and Social Media to send and receive informationthey used both communication media frequently. Table 3 shows the comparison between sending and receiving information in different methods of communication, using paired sample t-tests.

Table 3. Differences in sending and receiving communications $(N=113)$.

\begin{tabular}{lccccc}
\hline Method & $M($ Send) & $M$ (Receive) & $t$ & $d f$ & Sig. \\
\hline Email & 5.51 & 5.66 & -1.88 & 112 & .06 \\
Paper & 2.79 & 3.38 & -4.87 & 112 & $.00^{*}$ \\
Social Media & 3.94 & 4.03 & -0.67 & 112 & .50 \\
Face-to-Face & 4.47 & 4.22 & 2.92 & 112 & $.00^{*}$ \\
\hline$* p<.001$ & & & & &
\end{tabular}

Additionally, a majority of respondents indicated their preference for using Email (69\%) and Face-to-Face Interaction (23\%) when initiating communication with their support office, rather than Phone $(4 \%)$ or Social Media (3\%). Moreover, $66 \%$ of international students would prefer to receive emails on key updates from their support office at least 4 to 5 times per month. Ninety-two percent reported that they understood and felt comfortable using expected email etiquette at their institution and in the U.S.

\section{Social Media Preferences}

When asked about their use of social media channels, international students reported that YouTube was their primary social media platform both in their home country $(M=4.23)$ and at the university site $(M=4.531)$. They occasionally used Facebook in their home country $(M=4.07)$ and when on campus $(M=4.407)$. Paired-samples t-tests were conducted to 
compare the means of social media usage when international students are in their home country versus when they are on campus. There was a significant mean difference in the use of Facebook at home and in the U.S. $[t(112)=$ $2.28, p<.05]$, suggesting that international students used this platform more frequently when they are on campus than at home. There was no significant difference in how frequently international students used YouTube at home and in the U.S.

In looking at Chinese social media channels, Chinese students $(n=$ 41) indicated that, of the platforms they subscribed to, they most frequently used WeChat both in their home country $(M=3.0)$ and at the university $(M$ $=2.73)$. The students used RenRen least frequently at home $(\mathrm{M}=1.84)$ and in the U.S. $(M=1.40)$. Chinese students had a tendency to use WeChat $[t(40)=2.95, p<.001]$, Weibo $[t(40)=2.24, p<.05]$, and RenRen $[t(40)=$ $3.11, p<.001]$ more in their home country than when they were in the U.S. Table 4 shows the comparison between sending and receiving information in different methods of communication, using a paired sample t-test.

Table 4. Differences in social media usage at home and on campus $(\mathrm{N}=$ 113).

\begin{tabular}{lccccc}
\hline Channel & $\begin{array}{c}M \\
\text { (Home) }\end{array}$ & $\begin{array}{c}M \\
\text { (Campus) }\end{array}$ & $t$ & $d f$ & Sig. \\
\hline Facebook & 4.07 & 4.407 & -2.28 & 112 & $.02^{* *}$ \\
Instagram & 3.46 & 3.654 & -1.60 & 112 & .11 \\
Twitter & 2.70 & 2.699 & .08 & 112 & .93 \\
YouTube & 4.23 & 4.531 & -1.57 & 112 & .11 \\
LinkedIn & 3.32 & 3.548 & -1.53 & 112 & .12 \\
SnapChat & 2.35 & 2.415 & -.45 & 112 & .65 \\
\hline WeChat & 3.00 & 2.73 & 2.95 & 40 & $.00^{*}$ \\
Weibo & 2.52 & 2.23 & 2.24 & 40 & $.03^{* *}$ \\
RenRen & 1.84 & 1.40 & 3.11 & 40 & $.00^{*}$ \\
QQ & 2.20 & 2.04 & 1.27 & 40 & .21 \\
\hline$* p<.001, * * p<.05$ & & & &
\end{tabular}

\section{Messaging Content}

The survey asked international students about the different topics of information they would be interested in receiving from their support office, and how likely they were to share that same information with other students. While respondents stated that all listed topics were of interest to them, 
information on Academic Resources and Programs $(M=4.36)$ was the most highly rated, followed by Immigration $(M=4.23)$, Social and Cultural Events $(M=4.16)$, University Safety $(M=4.01)$, and Health and Wellness $(M=3.94)$. Students were not as eager to share information as they were with receiving it - they were somewhat interested in re-sharing information on Academic Resources and Programs $(M=3.88)$, Social and Cultural Events $(M=3.84)$, and Immigration $(M=3.79)$.

We conducted paired-samples t-tests to compare the means of receiving and sharing different topics of information. There was a significant mean difference in interest between receiving and sharing information on each listed topic, suggesting that, on average, international students were more interested in receiving information rather than re-sharing that same information: Immigration $[t(112)=5.09, p<.001]$; Academic Resources and Programs $[t(112)=5.53, p<.05]$; Social and Cultural events $[t(112)=3.34, p<.001]$; Health and Wellness $[t(112)=4.39 p<.001]$; and University Safety $[t(112)=3.68, p<.001]$. Table 5 shows the comparison between receiving and re-sharing information on different topics, using paired sample t-tests.

Table 5. Differences in receiving and sharing messaging content $(\mathrm{N}=113)$.

\begin{tabular}{lccccc}
\hline Content & $\begin{array}{c}M \\
\text { (Receive) }\end{array}$ & $\begin{array}{c}M \\
\text { (Share) }\end{array}$ & $t$ & $d f$ & Sig. \\
\hline Immigration & 4.23 & 3.79 & 5.09 & 112 & $.00^{*}$ \\
Academic Resources & 4.36 & 3.88 & 5.53 & 112 & $.00^{*}$ \\
Social and Cultural & 4.16 & 3.84 & 3.34 & 112 & $.00^{*}$ \\
Health and Wellness & 3.94 & 3.47 & 4.39 & 112 & $.00^{*}$ \\
University Safety & 4.01 & 3.68 & 3.68 & 112 & $.00^{*}$ \\
\hline
\end{tabular}

$* p<.001$

\section{DISCUSSION AND IMPLICATIONS}

As the role of ISS offices continues to evolve to accommodate a larger and more diverse population of international students, scholars, and families at U.S. institutions of higher education, communications will become an important area for growth within the profession. ISS offices should employ data-driven communications strategies with the goal of, first and foremost, ensuring that non-immigrant populations receive the information they need to maintain a legal status in the U.S. Beyond this, a collaborative communications strategy should seek to create a sense of community and 
belongingness amongst its international population and to connect these same people to key ISS programs and to other resources across campus.

This study represents a step by the university site's ISS office to support its immigration services and programming model with a tailored communications strategy that seeks to meet its audiences where they are with relevant and timely information. The data retrieved from this survey has produced a number of key implications for the university site, which are discussed below along with several examples of how they can be leveraged there and perhaps on other campuses to maximize student engagement.

\section{Email}

Email emerged as the most frequently used form of communication to both receive and send information amongst the international students surveyed. The majority of respondents indicated that they would like to receive four to five email messages per month (or approximately one per week) from their ISS office. While the literature suggests that the most successful communications strategies in higher education must reduce unnecessary email "noise" and diversify by employing additional digital channels (Education Advisory Board, 2017; Gikas \& Grant, 2013), it is clear that, at least from this study and at the university site, email cannot and should not be discarded as the lynchpin in an ISS communications strategy. Hence, the university's ISS office must emphasize developing and sending email communications regularly to international students, scholars, and university stakeholders with key calls to action and reminders ranging from immigration to upcoming cultural and social programs. An example would be weekly e-newsletters containing a calendar of events. Working closely with academic and co-curricular units to integrate messaging from the larger campus community would be another. To further support this communication tactic, the ISS office must collaborate with the university's Office of Communications and Marketing to define a standard operating procedure that guides support staff on how and when to strategically send out mass or personalized emails.

\section{Face-to-Face Interaction}

Face-to-Face interaction was the second most preferred form of communication amongst the international students surveyed, confirming that the role of in-person advisors remains integral in the process, especially when it comes to addressing questions or concerns. It is therefore key that a strong connection between advising, communications, and programming staff is established. Messages, particularly those pertaining to immigration regulations, must efficiently direct students back to ISS advisory staff for 
further support, and also inform them on how they can access the services and programs of the university's ISS office.

It is common for ISS offices to host a number of social and cultural programs, such as a weekly coffee hour, welcome receptions, and other recreational activities, throughout the year to help students adjust to campus and engage with others in the local community. Such events provide a high level of face-to-face interaction among attendees and can serve as a strategic platform for ISS staff and other support unit representatives to enable the Counseling Center, Career Services, and Residence Life, to connect in person and convey important information and resources to this community.

\section{Social Media}

While the results indicate that respondents did prefer certain social media platforms over others, it is not clear that all international students are using one channel over another to communicate and receive information. In fact, it appears that the students surveyed are active on multiple channels and that preferences differ between students. Employing a comprehensive communications strategy, weighing audiences, consulting with the central office of communications and marketing, and making strategic decisions about which social media platforms the ISS office should have an active presence on are some important factors to take into consideration. It is helpful to communicate key messages across all social media platforms to ensure equal access by all students, though it may be necessary to tailor content for increased engagement on each channel.

YouTube was the most frequently used social media platform amongst the students surveyed in this study despite research suggesting that Facebook is the most popular social networking site for international students. This indicates both the fast-paced environment of social media and the ever-growing importance of video, both on YouTube and other social media platforms. The university's ISS office must consider building social media content that tells the story of their community and promotes key campaigns, events, and calls-to-action throughout the year, using video content whenever possible. The ISS office should obtain support from the central office for communications or hire student employees with relevant know-how to develop video content if the office does not employ a communications specialist.

Of Chinese social media channels, We-Chat was the most frequently used, though there was a statistically significant difference in frequency of use that indicated the students surveyed are more active in their home community than they are during their time at the university site. With China being the top sending country of international students to the U.S., it 
is important for ISS offices to partner with the recruitment and admissions offices to explore a university-wide presence on WeChat with a central content calendar that targets students even before arrival to campus. Finding opportunities to employ Chinese students on campus or partnering with content expert units, such as the Confucius Institute and the Department of Foreign Languages, to translate content and maintain an official presence on the social media channel would be another strategy.

\section{A Holistic Communications Model}

Each of the key trends and communications methods outlined above require significant amounts of time, resources, and talent to implement. ISS communications strategies must and should not operate within a vacuum. While the ISS offices contribute the expertise in content and audience, the central office of communication supplies ample creative talent. In addition, coordination with a university's central office of communications and marketing ensures consistency of brand style and opportunities for the amplification of messaging. It also provides the ISS office with direct and quick access to resources for managing media requests, crisis and risk management issues, and campus-wide messaging.

In order to ensure successful implementation of a communications strategy, ISS offices must develop communications plans throughout the year, also including details on learning goals and outcomes, staffing, timelines, budgets, and strategic points of collaboration. When developing a communications plan, it is also important to understand how the ISS office will partner with expert units to leverage all of its communications channels and achieve its short and long-term goals. This includes both in-person, print and digital communications, such as email and social media outreach. It is important that communications plans are crafted in coordination with ISS programming staff.

This study demonstrates that while key trends exist, students maintain a diversity of communications preferences, all of which must be catered to, and assessed regularly, in order to ensure optimal success in outreach and engagement.

\section{Engagement Between Domestic and International Students}

International students often experience difficulties in developing friendships and connecting with both domestic and other international students on campus. This can disrupt their adjustment and integration to many aspects of campus life, especially if they do not receive the social and cultural support they need from their institution. Having a better understanding of the communications preferences of international students 
can support an ISS office in fostering engagement opportunities with the local campus community.

Based on some of the implications discussed in this study, the ISS office, which serves as the primary domestic host to international students on campus, has developed targeted communications strategies to effectively reach this community and encourage them to participate in campus-wide activities. Similarly, other service units have collaborated with the ISS office to guide their communications efforts and promote events and opportunities for meaningful, cross-cultural interactions among diverse groups of international and domestic students.

As an example, attendance at a weekly International Coffee Hour at the university site in this study has steadily increased as a result of a strong communications strategy and intentional collaborations with various partner offices on campus and in the local community. With over 200 in attendance each week, this program provides a platform for attendees to make friends, practice their language, learn about different cultures, and enjoy a free beverage and snacks. In addition to growth in new and repeat attendance among international students, a larger community of domestic students and scholars have also begun to attend this program. A meaningful communications and programming strategy has converted attendance into friendship.

\section{CONCLUSION}

Being a quantitative study administered at a large research institution, the reported findings were not meant to be generalizable in nature but rather serve as an impetus both for institutional change and for future research. It does not account for personal and cultural factors that may impact the preference and experience of international students nor does it include short term, credit mobility or English language training students. A larger sample size, a more diverse representation of students, and a comparative perspective from domestic students can further this area of research.

However, this study supports the argument for an intentional approach to ISS communications plans and, above all, reassures the importance of formal assessment and the frequent collection of analytics to drive strategy. The survey indicated several key trends that should inform the strategy of the university's ISS office communications strategy:

- Email remains the most preferred form of communication by international students, and should be an anchor component of the ISS communications strategy. 
- Face-to-Face interaction was the second most preferred form of communication amongst students, emphasizing the importance of ISS advisory staff.

- While the survey did show preferences for certain social media channels over others, it is not clear that all students prefer one over the other, meaning that the ISS office should adopt a diversified presence on social media.

- Collaboration with a central office of communications and marketing is key in ensuring the successful implementation of a holistic communications strategy.

As the international student population in the U.S. continues to grow and diversify, and as the digital landscape evolves, ISS offices should be prepared to expand, assess, and optimize their communications strategies on a regular basis in compliance and coordination with other institutional departments and support units in order to ensure student engagement, experience, and success on campus.

\section{REFERENCES}

Abe, J., Talbot, D.M., \& Geelhoed, R.J. (1998). Effects of a peer program on international student adjustment. Journal of College Student Development, 39(6), 539-547.

Alzougool, B., Chang, S., Gomes, C., \& Berry, M. (2013). Finding their way around: International students' use of information sources. Journal of Advanced Management Science, 1(1), 43-49.

Archer, W., Jones, E., \& Davison, J. (2010). A UK guide to enhancing the international student experience. London: UK Higher Education International Unit.

Argenti, P.A., Howell, R.A., \& Beck, K.A. (2005). The strategic communication imperative. MIT Sloan Management Review, 46(3). Retrieved from https://sloanreview.mit.edu/article/the-strategic-communication-imperative/

Astin, A.W. (1993). What matters in college? Liberal Education. Retrieved from https://doi.org/10.1057/palgrave.cpcs. 8140196

Bista, K. (2013). Internationalization in higher education: Needs and resources for international students. Review of Global Studies Literature, 4, 1-2.

Briggs, P., \& Ammigan, R. (2017). A collaborative programming and outreach model for international student support offices. Journal of International Students, 7(4), 1080-1095.

Burdett, J., \& Crossman, J. (2012). Engaging international students: An analysis of the Australian Universities Quality Agency (AUQA) reports. Quality Assurance in Education, 20(3), 207-222.

Choudaha, B.R., \& Schulmann, P. (2014). Bridging the gap recruitment and retention to improve international student experiences. NAFSA: Association of International Educators. 
Chang, S., \& Gomes, C. (2016). International students information seeking behaviour: Implications for international education. ISANA: International Education Association, Inc.

Dunkel, N., Bray, K., \& Wofford, A. (1989). Training and raising awareness in career knowledge. Gainesville, FL: University of Florida.

Dunne, C. (2009). Host students' perspectives of intercultural contact in an Irish university. Journal of Studies in International Education, 13(2), 222-239.

Education Advisory Board. (2017). Breaking through the student communications barrier. Retrieved from https://www.eab.com/technology/student-successcollaborative/members/events/webconferences/2017/breaking-through-thestudent-communications-barrier-for-leadership/eabondemand

Gikas, J., \& Grant, M.M. (2013). Mobile computing devices in higher education: Student perspectives on learning with cellphones, smartphones \& social media. The Internet and Higher Education, 19, 18-26.

Hallahan, K., Holtzhausen, D., van Ruler, B., Verčič, D. Sriramesh, K. (2007). Defining strategic communication. International Journal of Strategic Communication, 1(1), 3-35.

Hayes, R.L., \& Lin, H.R. (1994). Coming to America: Developing social support systems for international students. Journal of Multicultural Counseling and Development, 22(1), 7-16.

Hobsons Solutions. (2016). International Student Recruitment and University Marketing. Retrieved from http://www.hobsonssolutions.com/EMEA/OurInsight/Reports/Developing-A-Sustainable-International-Strategy-Us

Institute of International Education. (2017). Open doors report. Retrieved from https://www.iie.org/Research-and-Insights/Open-Doors/Data/InternationalStudents/All-Places-of-Origin

Jacobsen, W.C., \& Forste, R. (2011). The wired generation: Academic and social outcomes of electronic media use among university students. Cyberpsychology, Behavior, and Social Networking, 14(5), 275-280.

Jones, E. (2017). Problematising and reimagining the notion of "international student experience." Studies in Higher Education, 42(5), 933-943.

Kaczmarek, P.G., Matlock, G., Merta, R., Ames, M.H., \& Ross, M. (1994). An assessment of international college student adjustment. International Journal for the Advancement of Counselling, 17(4), 241-247.

Khawaja, N.G., \& Stallman, H.M. (2011). Understanding the coping strategies of international students: A qualitative approach. Australian Journal of Guidance and Counselling, 21(2), 203-224.

Knapp, G.J. (1979). College cocurricular activities: Who participates and what are the benefits? Doctoral dissertation, Los Angeles, CA: University of California, Los Angeles.

Knight, J. (2015). Updating the definition of internationalization. International Higher Education, 33, 2-3.

Korobova, N. (2012). A comparative study of student engagement, satisfaction, and academic success among international and American students. Graduate Theses and Dissertations. Retrieved from http://lib.dr.iastate.edu/etd/12367

Lee, J.J., \& Rice, C. (2007). Welcome to America? International student perceptions of discrimination. Higher Education, 53(3), 381-409. 
Lin, J.H., Peng, W., Kim, M., Kim, S.Y., \& LaRose, R. (2012). Social networking and adjustments among international students. New Media \& Society, 14(3), 421-440.

Park, N., Kee, K.F., \& Al, P.E.T. (2009). Being immersed in social networking environment: Facebook groups, uses and gratifications, and social outcomes. Cyberpsychology \& Behavior, 12(6), 729-733.

Robinson, S., \& Stubberud, H. (2012). Communication preference among university students. Academy of Educational Leadership Journal, 16(2), 105-142.

Rosser, V.J., Hermsen, J.M., Mamiseishvili, K., \& Wood, M.S. (2007). A national study examining the impact of SEVIS on international student and scholar advisors. Higher Education, 54(4), 525-542.

Saha, N., \& Karpinski, A. (2016). The influence of social media on international students' global life satisfaction and academic performance. In K. Bista \& C. Foster (Eds.), Campus support services, programs, and policies for international students (pp. 57-76). Hershey, PA: IGI Global.

Saw, G., Abbott, W., Donaghey, J., \& McDonald, C. (2013). Social media for international students - it's not all about Facebook. Library Management, 34(3), 156-174.

Sherry, M., Thomas, P., \& Chui, W.H. (2010). International students: A vulnerable student population. Higher Education, 60(1), 33-46.

Smith, C., \& Demjanenko, T. (2011). Solving the international students retention puzzle. Windsor, ON: University of Windsor.

Smith, R.A., \& Khawaja, N.G. (2011). A review of the acculturation experiences of international students. International Journal of Intercultural Relations, 35(6), 699-713.

Steyn, B. (2003). From "strategy" to "corporate communication strategy": A conceptualisation. Journal of Communication Management, 8(2), 168-183.

Ohio State University. (2017). Students' preferences for receiving communication from the university: A report from the student life survey. Retrieved from http://cssl.osu.edu/reports-data/

University of Kansas. (n.d.). Developing a plan for communication. Center for Community Health and Development. Retrieved from https://ctb.ku.edu/en/tableof-contents/participation/promoting-interest/ communication-plan/main

Vincent-Lancrin, S. (2007). Developing capacity through cross-border tertiary education. In R. Kagia and B. Ischinger (Eds.), Cross-border tertiary education: A way towards capacity development (pp. 47-108). Paris and Washington, DC: OECD and The World Bank.

\section{Appendix A}

Survey Instrument

\begin{tabular}{|l|rl|}
\hline Question & Scale & \\
\hline $\begin{array}{l}\text { 1.) How often do you use the } \\
\text { following communication methods to } \\
\text { regularly send important information } \\
\text { pertinent to your life at the }\end{array}$ & $\bullet$ & Very frequently $=5$ \\
\hline
\end{tabular}




\begin{tabular}{|c|c|}
\hline Question & Scale \\
\hline $\begin{array}{l}\text { University? } \\
\text { Email, Paper Communications, } \\
\text { Social Media, Word of Mouth (Face- } \\
\text { to-Face interactions) }\end{array}$ & $\begin{array}{ll}\text { - } & \text { Rarely }=2 \\
\text { - } & \text { Very Rarely }=1 \\
\text { - } & \text { Never }=0 \\
\text { - } & \text { Choose not to respond }=100 \\
\text { - } & \text { Indeterminate (no response) }=200\end{array}$ \\
\hline $\begin{array}{l}\text { 2.) How often do you use the } \\
\text { following communication methods to } \\
\text { regularly receive or observe } \\
\text { important information pertinent to } \\
\text { your life at the University? } \\
\text { Email, Paper Communications, } \\
\text { Social Media, Word of Mouth (Face- } \\
\text { to-Face interactions) }\end{array}$ & $\begin{array}{ll}\text { - } & \text { Very frequently }=5 \\
\text { - } & \text { Frequently }=4 \\
\text { - } & \text { Occasionally }=3 \\
\text { - } & \text { Rarely }=2 \\
\text { - } & \text { Very Rarely }=1 \\
\text { - } & \text { Never }=0 \\
\text { - } & \text { Choose not to respond }=100 \\
\text { - } & \text { Indeterminate (no response) }=200 \\
\end{array}$ \\
\hline $\begin{array}{l}\text { 3.) How many times per month } \\
\text { would you like to receive official } \\
\text { emails from OISS focused on key } \\
\text { updates about your life at the } \\
\text { University? }\end{array}$ & $\begin{array}{ll}\text { - } & 5 \text { or more times per month }=4 \\
\text { - } & 4 \text { times per month }=3 \\
\text { - } & 3 \text { times per month }=2 \\
\text { - } & 1-2 \text { times per month }=1 \\
\text { - } & \text { Never }=0 \\
\text { - } & \text { Choose not to respond }=100 \\
\text { - } & \text { Indeterminate (no response) }=200 \\
\end{array}$ \\
\hline $\begin{array}{l}\text { 4.) Rate the amount to which you } \\
\text { agree with the following statement: } \\
\text { "I understand and feel comfortable } \\
\text { using expected email etiquette in the } \\
\text { United States." }\end{array}$ & $\begin{array}{ll}\text { - } & \text { Strongly Agree }=5 \\
\text { - } & \text { Agree }=4 \\
\text { - } & \text { Neither Agree nor Disagree }=3 \\
\text { - } & \text { Disagree }=2 \\
\text { - } & \text { Strongly Disagree }=1 \\
\text { - } & \text { Choose not to respond }=100 \\
\text { - } & \text { Indeterminate (no response) }=200\end{array}$ \\
\hline $\begin{array}{l}\text { 5.) How do you prefer to initiate } \\
\text { communication with OISS? }\end{array}$ & $\begin{array}{ll}\text { - } & \text { Email } \\
\text { - } & \text { Social Media } \\
\text { - } & \text { In-person meeting } \\
\text { - } & \text { Phone call } \\
\text { - } & \text { Choose not to respond }=100 \\
\text { - } & \text { Indeterminate (no response) }=200 \\
\end{array}$ \\
\hline $\begin{array}{l}\text { 6.) How often do you use the } \\
\text { following social media channels } \\
\text { while in your home country? } \\
\text { Facebook, Instagram, Twitter, } \\
\text { LinkedIn, SnapChat, WeChat, Weibo, } \\
\text { RenRen, } Q Q\end{array}$ & $\begin{array}{ll}\text { - } & \text { Very frequently }=5 \\
\text { - } & \text { Frequently }=4 \\
\text { - } & \text { Occasionally }=3 \\
\text { - } & \text { Rarely }=2 \\
\text { - } & \text { Very Rarely }=1 \\
\text { - } & \text { Never }=0 \\
\text { - } & \text { Choose not to respond }=100\end{array}$ \\
\hline
\end{tabular}




\begin{tabular}{|c|c|}
\hline Question & Scale \\
\hline & - $\quad$ Indeterminate (no response) $=200$ \\
\hline $\begin{array}{l}\text { 7.) How often do you use the } \\
\text { following social media channels } \\
\text { while you are here at the University? } \\
\text { Facebook, Instagram, Twitter, } \\
\text { LinkedIn, SnapChat, WeChat, Weibo, } \\
\text { RenRen, } Q Q\end{array}$ & $\begin{array}{ll}\text { - } & \text { Very frequently }=5 \\
\text { - } & \text { Frequently }=4 \\
\text { - } & \text { Occasionally }=3 \\
\text { - } & \text { Rarely }=2 \\
\text { - } & \text { Very Rarely }=1 \\
\text { - } & \text { Chover }=0 \\
\text { - } & \text { Indeterminate (no response) }=200 \\
\end{array}$ \\
\hline $\begin{array}{l}\text { 8.) How strongly are you interested } \\
\text { in receiving information on the } \\
\text { following topics related to your life } \\
\text { at the University? } \\
\text { Immigration, Academic events \& } \\
\text { programs, Cultural and social events } \\
\text { and programs, Health \& Wellness, } \\
\text { University Safety }\end{array}$ & $\begin{array}{ll}\text { - } & \text { Very Interested }=5 \\
\text { - } & \text { Interested }=4 \\
\text { - } & \text { Neither Interested nor Uninterested }= \\
& 3 \\
\text { - } & \text { Uninterested }=2 \\
\text { - } & \text { Very Uninterested }=1 \\
\text { - } & \text { Choose not to respond }=100 \\
\text { - } & \text { Indeterminate (no response) }=200 \\
\end{array}$ \\
\hline $\begin{array}{l}\text { 9.) How likely are you to re-share } \\
\text { communications you receive on the } \\
\text { following topics with your fellow } \\
\text { peers? } \\
\text { Immigration, Academic events \& } \\
\text { programs, Cultural and social events } \\
\text { and programs, Health \& Wellness, } \\
\text { University Safety }\end{array}$ & $\begin{array}{ll}\text { - } & \text { Very Likely }=5 \\
\text { - } & \text { Likely }=4 \\
\text { - } & \text { Neither Likely nor unlikely }=3 \\
\text { - } & \text { Unlikely }=2 \\
\text { - } & \text { Very unlikely }=1 \\
\text { - } & \text { Choose not to respond }=100 \\
\text { - } & \text { Indeterminate (no response) }=200\end{array}$ \\
\hline $\begin{array}{l}\text { 10.) Rate the amount to which you } \\
\text { agree with the following statement: } \\
\text { "In general, I am able to fully } \\
\text { understand the meaning of the } \\
\text { language and jargon used on } \\
\text { American-run social media } \\
\text { accounts." }\end{array}$ & $\begin{array}{ll}\text { - } & \text { Strongly Agree }=5 \\
\text { - } & \text { Agree }=4 \\
\text { - } & \text { Neither Agree nor Disagree }=3 \\
\text { - } & \text { Disagree }=2 \\
\text { - } & \text { Strongly Disagree }=1 \\
\text { - } & \text { Choose not to respond }=100 \\
\text { - } & \text { Indeterminate (no response) }=200\end{array}$ \\
\hline $\begin{array}{l}\text { 11.) Rate the amount to which you } \\
\text { agree with the following statement: } \\
\text { "In general, I pay attention to posters } \\
\text { and flyers that are hanging around } \\
\text { campus." }\end{array}$ & $\begin{array}{ll}\text { - } & \text { Strongly Agree }=5 \\
\text { - } & \text { Agree }=4 \\
\text { - } & \text { Neither Agree nor Disagree }=3 \\
\text { - } & \text { Disagree }=2 \\
\text { - } & \text { Strongly Disagree }=1 \\
\text { - } & \text { Choose not to respond }=100 \\
\text { - } & \text { Indeterminate (no response) }=200 \\
\end{array}$ \\
\hline $\begin{array}{l}\text { 12.) Rate the amount to which you } \\
\text { agree with the following statement: }\end{array}$ & $\begin{array}{ll}\text { - } & \text { Strongly Agree }=5 \\
\text { - } & \text { Agree }=4\end{array}$ \\
\hline
\end{tabular}




\begin{tabular}{|c|c|}
\hline Question & Scale \\
\hline $\begin{array}{l}\text { "While attending school in the } \\
\text { United States, I prefer to receive } \\
\text { official communications in my native } \\
\text { language." }\end{array}$ & $\begin{array}{ll}\text { - } & \text { Neither Agree nor Disagree }=3 \\
\text { - } & \text { Disagree }=2 \\
\text { - } & \text { Strongly Disagree }=1 \\
\text { - } & \text { Choose not to respond }=100 \\
\end{array}$ \\
\hline $\begin{array}{l}\text { 13.) How proficient would you say } \\
\text { you are in reading, listening, and } \\
\text { speaking the English Language? }\end{array}$ & $\begin{array}{ll}\text { - } & \text { Very proficient }=4 \\
\text { - } & \text { Proficient }=3 \\
\text { - } & \text { Somewhat proficient }=2 \\
\text { - } & \text { Not proficient }=1 \\
\text { - } & \text { Choose not to respond }=100 \\
\text { - } & \text { Indeterminate/no response }=200 \\
\end{array}$ \\
\hline $\begin{array}{l}\text { 14.) Please indicate your home } \\
\text { country. }\end{array}$ & $\begin{array}{ll}\text { - } & \text { Coded after collection } \\
\text { - } & \text { Choose not to respond }=100 \\
\text { - } & \text { Indeterminate/no response }=200\end{array}$ \\
\hline $\begin{array}{l}\text { 15.) Please indicate your native } \\
\text { language. }\end{array}$ & $\begin{array}{ll}\text { - } & \text { Coded after collection } \\
\text { - } & \text { Choose not to respond }=100 \\
\text { - } & \text { Indeterminate/no response }=200\end{array}$ \\
\hline $\begin{array}{l}\text { 16.) Are you an undergraduate, Ph.D. } \\
\text { or Master's student? }\end{array}$ & $\begin{array}{ll}\text { - } & \text { Undergraduate student }=1 \\
\text { - } & \text { Master's student }=2 \\
\text { - } & \text { Ph.D. student }=3 \\
\text { - } & \text { Choose not to respond }=100 \\
\text { - } & \text { Indeterminate/no response }=200\end{array}$ \\
\hline $\begin{array}{l}\text { 17.) Please indicate your current } \\
\text { location of residence (City, State, } \\
\text { Country). }\end{array}$ & $\begin{array}{ll}\text { - } & \text { Coded after collection } \\
\text { - } & \text { Choose not to respond }=100 \\
\text { - } & \text { Indeterminate/no response }=200\end{array}$ \\
\hline
\end{tabular}

RAVICHANDRAN AMMIGAN is Executive Director for International Services at the University of Delaware, USA. He is also a PhD candidate at the Center for Higher Education Internationalisation, Università Cattolica del Sacro Cuore, Milan, Italy. His research examines international student satisfaction with various aspects of the university experience across campuses globally. Email: rammigan@udel.edu

KAITLYN N. LAWS is a Communications Specialist in the Institute for Global Studies and Office for International Students and Scholars at the University of Delaware. She received an Honors Bachelor's Degree with Distinction in Anthropology in 2014 from the University of Delaware and is currently pursuing a Master's degree in Urban Affairs \& Public Policy. Email: nlaws@udel.edu 